\title{
Genetic variation and characterization of the sucrose synthase 2 gene (Sus2) in sugarcane based molecular markers
}

\author{
RINA SRI KASIAMDARI ${ }^{1}$, DEA FEBIANSI ${ }^{2}$, HERI PRABOWO ${ }^{3}$, GANIES RIZA ARISTYA ${ }^{2, \bullet}$, \\ ARNI MUSTHOFA ${ }^{4}$ \\ ${ }^{1}$ Plant Systematics Laboratory, Faculty of Biology, Universitas Gadjah Mada. Jl. Teknika Selatan, Sekip Utara, Sleman 55281, Yogyakarta, Indonesia \\ ${ }^{2}$ Genetic and Breeding Laboratory, Faculty of Biology, Universitas Gadjah Mada. Jl. Teknika Selatan, Sekip Utara, Sleman 55281, Yogyakarta, \\ Indonesia. Tel./fax.: +62-274-580839, vemail: ganies_riza@ugm.ac.id \\ ${ }^{3}$ Plant and Disease Laboratory, ${ }^{3}$ Indonesian Sweetener and Fiber Crops Research Institute. Jl. Raya Karangploso, Malang 65152, East Java, Indonesia \\ ${ }^{4}$ Faculty of Biology, Universitas Gadjah Mada. Jl. Teknika Selatan, Sekip Utara, Sleman 55281, Yogyakarta, Indonesia
}

Manuscript received: 17 May 2019. Revision accepted: 2 October 2019.

\begin{abstract}
Kasiamdari RS, Febiansi D, Prabowo H, Aristya GR, Musthofa A. 2019. Genetic variation and characterization of the sucrose synthase 2 gene (Sus2) in sugarcane based molecular markers. Biodiversitas 20: 3087-3096. Sugarcane (Saccharum spp.) genotype is one of the sugar-producing plants and an important commodity to support the community's economy. Plant breeders continuously cross-breed these plants to obtain cultivars with desirable traits to produce a variety of new phenotypes. An analysis of variation at gene-level is carried out as an important step in plant breeding programs. The purpose of the present study was to determine genetic variation and characterize the sucrose synthase 2 gene (Sus2) based on molecular markers. Twenty sugarcane cultivars were sampled from Indonesian Sweetener and Fiber Crops Research Institute (BALITTAS) Malang and four sugarcane cultivars from PT. Madu Baru in Polosio A Plantation, Poncosari, Srandakan, Bantul Regency, Yogyakarta. DNAs were amplified using two primer pairs, i.e. AI and SMC226CG. The genetic variations of the twenty-four sugarcane cultivars were analyzed by constructing a dendrogram of the Amplified DNA using Multi-Variate Statistical Package (MVSP) software. The results showed that there were three large clusters, namely Cluster A consisting of 'PS 865', 'PS 951', 'PS 921', and 'PS 58', with a similarity index of 57\%; Cluster B consisting of the sugarcane 'Kentung', with a similarity index of 33\%; and cluster C consisting of the sugarcane 'PSDK 923', 'PSBM 901', 'TLH 2', 'BL', 'PSJT 941', 'KK', 'PS 80.1649', 'PSCO 902', 'PS 80,910', 'PS 882', 'PS 862', 'PS 851', 'PS 881', 'PS 865', 'PS 384', 'VMC 76-16', 'BZ 132', 'PS 891', 'PS 41' with a similarity index of $60 \%$. Polymorphisms occurred after the DNAs were amplified and after the bands appeared in heterozygous and homozygous individuals. In sugarcane, the Sus2 gene when detected by the molecular marker primer AI showed high-sucrose sugarcane; whereas the Sus2 gene detected by the primer SMC226CG showed low-sucrose sugarcane. Results of the present study showed that all sugarcane samples were detected as having low sucrose except Bulu Lawang and Kentung cultivars.
\end{abstract}

Keywords: Genetic variations, molecular markers, polymorphisms, sugarcane, Sus2 gene

\section{INTRODUCTION}

Sugarcane (Saccharum spp.) genotype is one of the sugar-producing cultivated crops (Scortecci et al. 2012). Commercial hybrid cultivars of sugarcane descended from interspecific hybridization between high sucrose sugarcane clone Saccharum officinarum and a low sucrose clone Saccharum spontaneum (Bull and Glasziou 1979). S. officinarum was selected as very high sucrose (65 to 100 $\mathrm{mg} / \mathrm{g}$ tissue) genotypes, whereas $S$. spontaneum was very low sucrose ( 2 to $25 \mathrm{mg} / \mathrm{g}$ tissue) genotypes (Vinayak et al. 2010). It is also one of the important commodities for the people and economy of Indonesia. According to the Ministry of Agriculture (2015), the national sugar consumption in 2015 was 5.9 million tons and will $10 \%$ continue increasing annually. However, the national sugar production continues to decline and only reaches 2.9 million tons for a year. The main product of sugarcane is sucrose. Sucrose as a carbon source for living activities of endophytic bacteria is distributed unevenly on the sugarcane stalk segment (Kumar et al. 2016). There is a difference in the sucrose contents among cultivars, which is influenced by the plant development stages (age), genetic, and environmental factors (Rodiyah et al. 2004). The process of identifying genotypes of high-sucrose sugarcane plants in the early stages of growth is important for plant breeding programs as a means to increase the productivity of processed sugarcane crops (Rutherford et al. 2014).

The sucrose synthase 2 (Sus2) is a very important enzyme-encoding gene since it encodes the enzyme for sucrose metabolism in sugarcane (Lingle and Dyer 2004). A comparison of sequences of the promoter region of Sus 2 gene in high and low sucrose types revealed that promoter sequences of the gene were polymorphic between genotypes and therefore sugarcane species that are known to be polyploids would seem to contain multiple forms of the Sus 2 gene. The sequence differences in the promoter region were primarily due to different indels (insertions deletions) ranging from 233 to $247 \mathrm{bp}$ and the possibility of using these variable indels as PCR markers for identifying different alleles of Sus 2 gene in high and low sucrose genotypes was explored. According to Vinayak et al. (2010), ten primers that can detect polymorphisms in the promoter region of Sus 2 genes, namely AI, SS and SPS 
primers which are designed based on the sequence of nucleotides for invertase enzymes, sucrose synthase, sucrose phosphate synthase enzymes, and MSSCIR43, MSSCIRI, SMC226CG, SMC1039CG sequences and invertase enzymes, sucrose synthase, sucrose phosphate synthase enzymes, and MSSCIR43, MSSCIRI, SMC226CG, SMC1039CG and SCB07 which has a relationship with the sucrose accumulation process so that it is able to identify low-sucrose or high-sucrose cultivars. Therefore, the present study was conducted to identify and analyze one of the sucrose-encoding genes in sugarcane plants, namely the Sus 2 gene, using molecular markers.

Plant breeders continuously cross-breed these plants to obtain cultivars with desirable traits to produce a variety of new phenotypes. An analysis of variations at the gene level is carried out as an important step in plant breeding programs. Amplicon of AI primer pairs showed that sugarcane cultivar samples have high-sucrose encoding genes since, when identified with AI primer, they produced a size of 500 bp, however, when identified with SMC226CG primer, they produced a size of 920 bp showed that sugarcane cultivars samples have low-sucrose encoding genes (Vinayak et al. 2010). The purpose of the present study was to determine genetic variation and characterize the sucrose synthase gene (Sus2) based on molecular markers.

\section{MATERIALS AND METHODS}

\section{Plant materials}

The twenty-four samples of sugarcane cultivar leaves used in the study were PS 862, PSBM (Bunga Mayang) 901, KK (Kidang Kencana), BZ 132, BL (Bulu-Lawang), PSCO 902, PSJT 941, Kentung, PS 864, PS 865, PS 881, PS 882, PS 891, PS 921, PS 951, PS 80,910, PS 41, PS 58, PS 384, PS 851, and PS 80,1649 derived from the Indonesian Sweetener and Fiber Crops Research Institute (BALITTAS) Malang, and BZ 132, TLH 2, PSDK 923, VMC 76-16 originating from open nursery of PT. Madu Baru in Polosio A plantation, Poncosari, Srandakan, Bantul, Yogyakarta. Cultivars were weighed to $0.32 \mathrm{~g}$ and subjected to DNA isolation using the Nucleon Phytopure kit. The research was conducted from February 2019 to August 2019 in Genetic and Breeding Laboratory, Faculty of Biology, University of Gadjah Mada, Indonesia.

\section{Procedures}

Quantitative and qualitative tests of DNAs

A total of $2 \mu \mathrm{L}$ of genomic DNAs were tested quantitatively using a spectrophotometer. The DNA concentration was calculated using the absorbance formula of $\lambda 260 \times 50 \times$ dilution $\mu \mathrm{g} / \mathrm{mL}$. The DNA purity value can be measured by the absorbance of $\lambda 260 / \lambda 280$ with a good purity ratio being in the range of 1.8-2.0 (Sambrook and Russel 1989). The qualitative analysis of genomic DNA was performed by the electrophoresis technique. Genomic DNA samples were mixed with a loading dye on a parafilm paper with a ratio of loading dye to the sample DNAs of 1:5. The electrophorator was run until the DNA samples reached $2 / 3$ of the length of the gel. Finally, the electrophoresis results were observed using gel doc and Optilab connected to the computer. Genomic DNAs would appear right below the well since its size remained very large.

\section{Amplification of Sus2 using the PCR Method}

DNAs were amplified using a Bio-Rad PCR machine according to the number of samples to be amplified. The premix consisted of $8.5 \mu \mathrm{l}$ of sterile $\mathrm{ddH}_{2} \mathrm{O}, 0.5 \mu \mathrm{l}$ of reverse primer, $0.5 \mu \mathrm{l}$ of diluted forward primer and $12.5 \mu \mathrm{l}$ of PCR kit. The AI forward primer sequence was 5' CAA GTT CTA CGC GTC CAA GAC 3' and the AI reverse primer sequence was 5' CAG ATG TCC GTG ACC ATT AGT 3'. The SMC226CG forward primer sequence was 5' GAG GCT CAG AAG CTG GCA T 3, , and the SMC226CG reverse primer sequence was 5' ACC CTC TAT TTC CGA GTT GGT 3' (Vinayak et al. 2010). These primers used because amplicon of AI primer pairs showed that sugarcane cultivar samples have high-sucrose encoding genes since, when identified with AI primer, they produced a size of $500 \mathrm{bp}$, however, when identified with SMC226CG primer, they produced a size of $920 \mathrm{bp}$ showed that sugarcane cultivars samples have low-sucrose encoding genes (Vinayak et al. 2010). Subsequently, all mixtures for the PCR premix were included in a special PCR tube. Then, the premix was added with the DNA template. The replication of each PCR was 40 times.

The PCR cycle has four stages. The denaturation stage was performed for 1 minute at $94^{\circ} \mathrm{C}$, the annealing stage was performed for 75 seconds at $52^{\circ} \mathrm{C}$ to $57^{\circ} \mathrm{C}$, the extension stage was carried out for 45 seconds at $72^{\circ} \mathrm{C}$, and, finally, the final extension stage was carried out for 70 seconds at $72^{\circ} \mathrm{C}$. The denaturation, annealing and elongation cycles were repeated 40 times (Vinayak et al. 2010).

\section{Data analysis}

The PCR product electrophoresis data were subsequently converted to a 0-1 matrix. The appearing DNA band was converted as 1 and the non-appearing band was converted as 0 . The size of DNA bands was determined by comparing the traveled distance of the sample DNA band using the 100-bp DNA marker. The fragments of the amplification products were analyzed using the Multivariate Statistical Package (MVSP) by calculating the traveled distance of the bands on the 100-bp marker and subsequently calculating the basepair log. Upon calculation, the traveled distance of the marker was plotted on the graph to obtain a standard curve and the linear equation was calculated. The DNA band size generated by the primer was subsequently determined by converting the traveled distance of DNA bands to the equation and then the data were converted to an anti-log form. Cluster analysis of binary data based on the DNA band profile that appears from DNA amplification in the two primers. The similarity level is then used to construct the dendrogram with UPGMA with an arithmetic mean method. Upon completion of the conversion of data into positive and negative matrices, the similarity index was calculated and a dendrogram was constructed using the Multivariate Statistical Package (MVSP 3.1A) program. 
In the phylogenetic approach, a group of organisms in which members have many similarities in character or characteristics is considered to have a very close relationship and are thought to have descended from a common ancestor. The resulting Sus2 sequences with specific molecular markers on sugarcane samples were analyzed using the GeneStudio pro program to be edited manually by looking at ambiguous peaks and nucleotides. Sequence results were then analyzed using the online Nucleotide BLAST (Madden 2013) on the NCBI website (https://blast.ncbi.nlm.nih.gov/Blast.cgi). The online Nucleotide BLAST analysis produced similarity and identity indicating the similarity of samples with species in the Gene Bank database. Subsequently, FASTA from the results of online Nucleotide BLAST was combined with FASTA resulting from DNASTAR in notepad. The results of online Nucleotide BLAST analysis were then used to predict the species of the samples under study. Upon completion of BLAST, a contig analysis was carried out and the areas not deriving from the consensus of the sample sequences were removed. Contig is a reconstruction of a series of overlapping parts of DNA.

\section{RESULTS AND DISCUSSION}

\section{Results}

Electrophoresis is a way of separating molecules based on charge and size (Vinayak et al. 2010). Separation of different sizes of genomic DNA molecules were obtained from 24 sugarcane cultivars. The genome DNA isolation was success, indicated by the size of the band DNA is more than $10 \mathrm{Mbp}$ under the wall and the DNA purity value can be measured by the absorbance of $\lambda 260$ to $\lambda 280$ with good purity ratio being in the range of 1.8-2.0 (Figure 1).

Each amplification product with a specific target fragment will produce an amplification band of a specific size. According to Vinayak et al (2010), the size of the fragments of amplified AI primer pairs is 50, 180, 210, 350,390 , and 500 bp. However, it is only the 500-bp DNA band that can indicate that the sugarcane plant has relatively high sucrose contents. The sizes of the fragments of amplified SMC226CG primer were 90, 180, 320, 430, 550 and 920 bp. However, it is only the 920-bp DNA band that can indicate that the sugarcane plant has relatively low sucrose contents. The results of amplification of AI primer pairs showed the formation of fragments of varying sizes, namely $351,495,502,720,754,882$, and $1205 \mathrm{bp}$, in twenty-four sugarcane samples (Figure 2).

Results of amplification of AI primer pairs (Figure 2) and SMC226CG (Figure 3) showed that all sugarcane cultivar samples have low-sucrose when identified with AI primer, they did not produce a size of $500 \mathrm{bp}$. However, when identified with SMC226CG primer, they produced size of 920 bp except for Bulu Lawang (BL) and Kentung cultivars. Number of DNA and polymorphic bands generated by AI and SMC226CG primers were presented in Table 1.

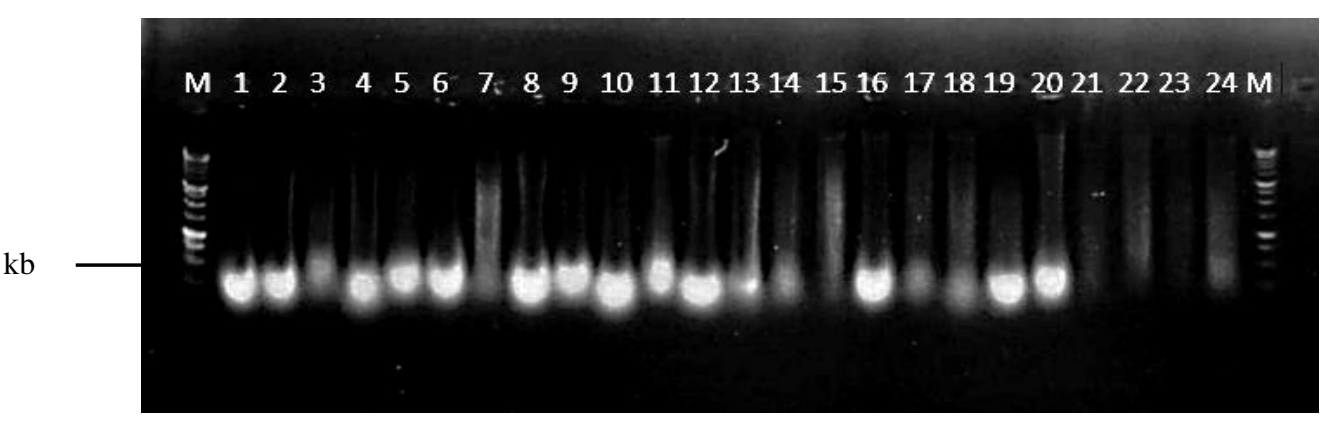

Figure 1. Electrophoregram of genomic DNAs of 24 sugarcane cultivars. M: Marker $1 \mathrm{~kb}, 1$ : PS 41, 2: PS 58, 3: PS 384, 4: PS 851, 5: PS 862, 6: PS 864, 7: PS 865, 8: PS 881, 9: PS 882, 10: PS 891, 11: PS 921, 12: PS 951, 13: PS 80.910, 14: PS 80. 1649, 15: PSCO 902, 16: PSBM 901, 17: PSJT 941, 18: BL, 19: Kentung, 20: Kidang Kencana, 21: BZ 132, 22: TLH 2, 23: PSDK 923, 24 : VMC 76-16.

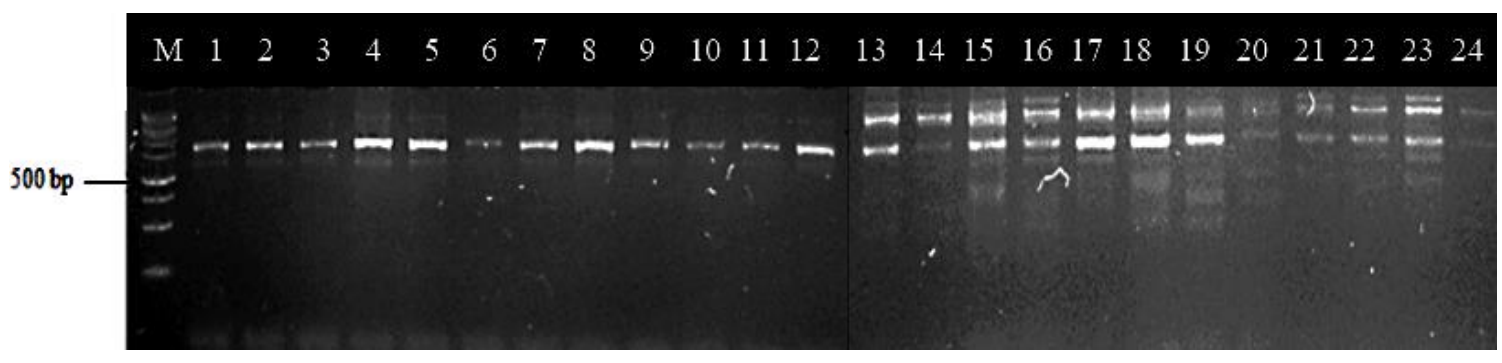

Figure 2. Electrophoregram of PCR of amplified DNAs with AI primer. M: 100-bp marker. $1 \mathrm{~kb}, 1$ : PS 41, 2: PS 58, 3: PS 384, 4: PS 851, 5: PS 862, 6: PS 864, 7: PS 865, 8: PS 881, 9: PS 882, 10: PS 891, 11: PS 921, 12: PS 951, 13: PS 80.910, 14: PS 80. 1649, 15: PSCO 902, 16: PSBM 901, 17: PSJT 941, 18: BL, 19: Kentung, 20: Kidang Kencana, 21: BZ 132, 22: TLH 2, 23: PSDK 923, 24: VMC 76-16. 
Table 1. DNA polymorphism detected primers for 24 sugarcane cultivars

\begin{tabular}{lccc}
\hline Primers & Number of DNA bands & Polymorphic DNA bands & Monomorphic DNA bands \\
\hline AI & 6 & 5 & 1 \\
SMC226CG & 6 & 2 & 4 \\
\hline
\end{tabular}

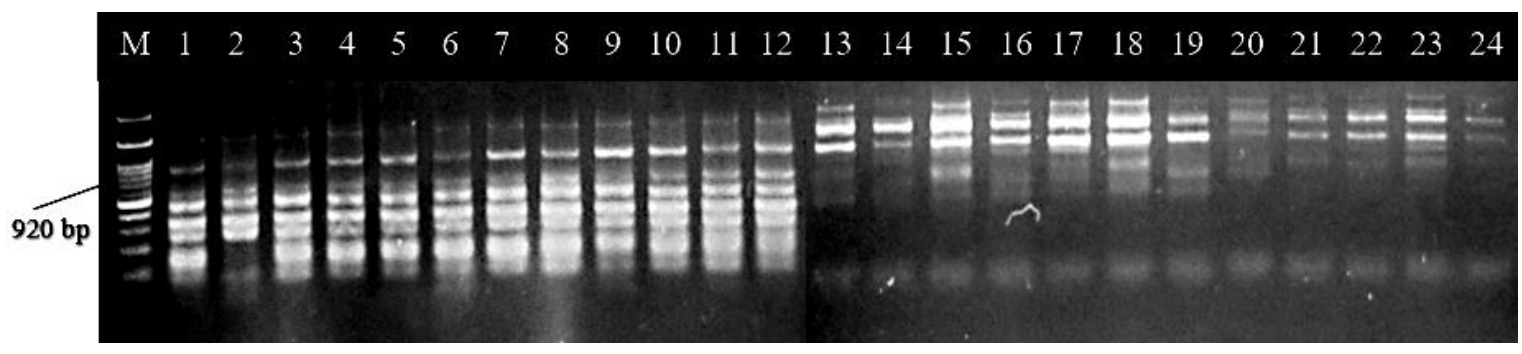

Figure 3. Electrophoregram of PCR of amplified DNAs with SMC226CG primer. M: 100-bp marker. $1 \mathrm{~kb}, 1$ : PS 41, 2: PS 58, 3: PS 384, 4: PS 851, 5: PS 862, 6: PS 864, 7: PS 865, 8: PS 881, 9: PS 882, 10: PS 891, 11: PS 921, 12: PS 951, 13: PS 80.910, 14 : PS 80. 1649, 15: PSCO 902, 16: PSBM 901, 17: PSJT 941, 18: BL, 19: Kentung, 20: Kidang Kencana, 21: BZ 132, 22: TLH 2, 23: PSDK 923, 24: VMC 76-16.

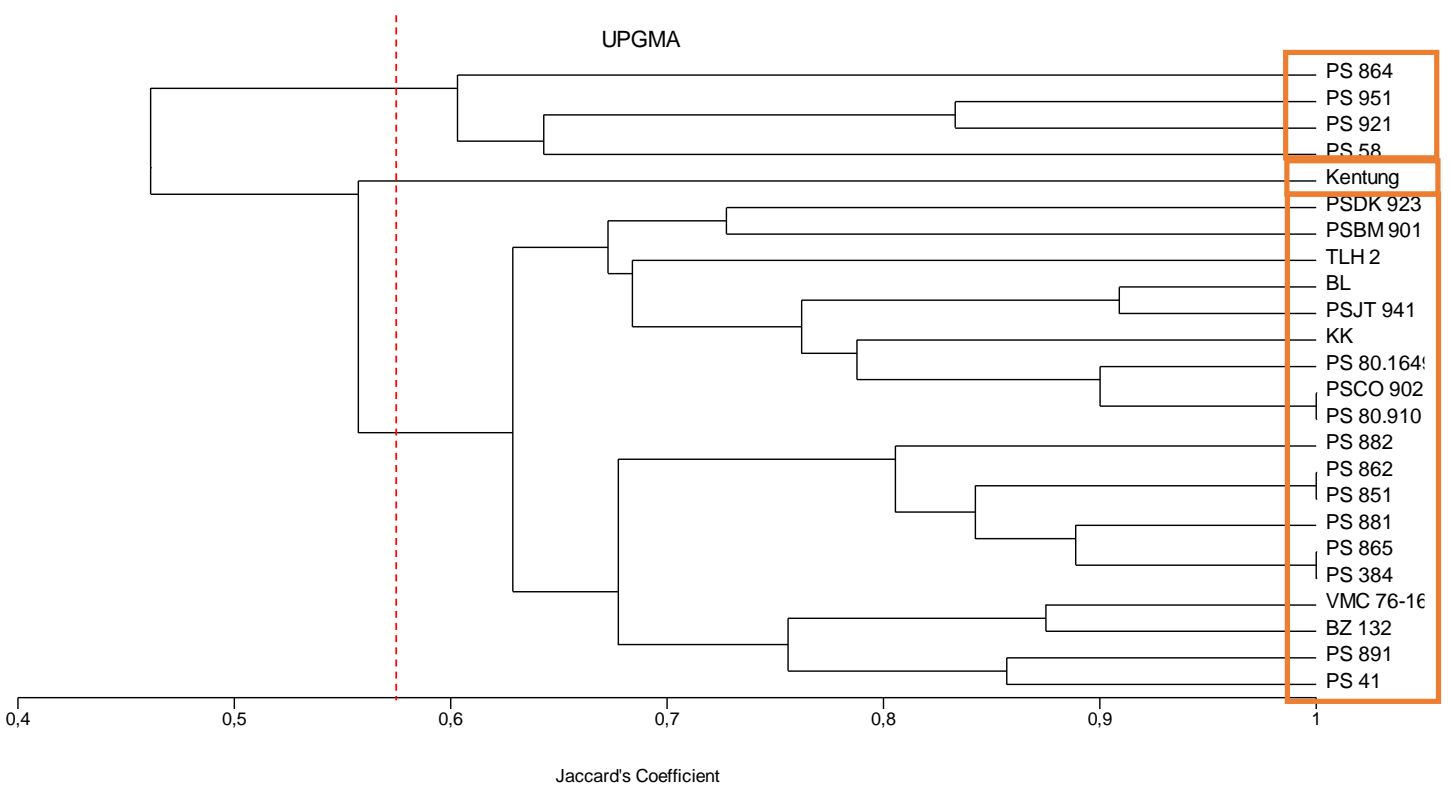

Figure 4. Dendrogram of similarity in twenty-four sugarcane cultivars based on high-sucrose encoding genes with the UPGMA program

The similarity relationship is obtained from the level of character similarity among individuals without any specialization of certain characters. In the present study, the character used was the amplified fragments from the PCR method. The similarity dendrogram shows three clusters. Cluster A consists of 'PS 865', 'PS 951', 'PS 921', and 'PS 58 '; Cluster B consists of 'Kentung'; and Cluster C consists of 'PSDK 923', 'PSBM 901', 'TLH 2', 'BL', 'PSJT 941', 'KK', 'PS 80.1649', 'PSCO 902', 'PS 80.910', 'PS 882', 'PS 862', 'PS 851', 'PS 881', 'PS 865', 'PS 384', 'VMC 76-16', 'BZ 132', 'PS 891', 'PS 41' (Figure 4). In general, the clustering illustrates the difference in the sequences of Amplified DNA. The three clusters are formed by the kinship of sucrose contents related to acid invertase enzyme and also sucrose-synthesizing enzymes in sugarcane.

Results of multiple sequence alignment of Sus 2 using the molecular marker AI and SMC226CG primers showed a difference in nucleotide base sequences in Sus2 from analog gene sequences in Gene Bank. Each gene has a different band length. The sugarcane samples used for sequences, PSJT 941, PS 80.1649, and Kidang Kencana have the shortest sequence size since the primers used are only capable of doing amplification at a certain length, making the overall size of the gene not amplified. A comparison sequence of the promoter region of this gene in high and low sucrose types revealed that promoter sequences of the gene were polymorphic between genotypes and therefore sugarcane species that are known to be polyploids would seem to contain multiple forms of the Sus 2 gene. The sequence differences in the promoter region were primarily due to different indels (insertions deletions) ranging from 233 to $247 \mathrm{bp}$ and the possibility of using these variable indels as PCR markers for identifying different alleles of Sus 2 gene in high and low sucrose 
genotypes was explored. Based on these observations, Vinayak et al. (2010) designed set ten primers (Table 2).

Results of BLAST on NCBI with AI primer (Table 3) showed that PSJT 941 sugarcane samples had kinship with the Saccharum hybrid cultivar GT28 (SAI) of $80.85 \%$, Saccharum hybrid cultivar FN-28 of $80.62 \%$, Saccharum robustum of $80.62 \%$, Saccharum hybrid cultivar GT28 (SAI9) of $80.40 \%$, Saccharum hybrid cultivar Pindar (ShinvA) $80.31 \%$, Saccharum officinarum of $80.18 \%$, Saccharum hybrid cultivar FN-41 of $95.24 \%$, Saccharum hybrid cultivar Pindar AY of 95.24\%, Saccharum hybrid cultivar GT28 (SAI6) of $79.96 \%$. The gene sequences of sugarcane PSJT 941 had a fairly high similarity of $80.85 \%$ to Sus2 Saccharum hybrid cultivar GF28 (SAI5) thus, it can be assumed that the above plants have a kinship based on the closeness with Sus2. Sus2 is sugarcane sucrose metabolizing enzyme-encoding gene, one of which is acid invertase enzyme which could be detected in the present study using the molecular marker primer AI.
Based on the results of the analysis obtained by conducting BLAST at NCBI using the SMC226CG primer (Table 4) the results showed that sugarcane samples from PS 80.1694 had a high similarity index of $96.30 \%$ with Saccharum officinarum cultivars 28NG210 and Saccharum hybrid cultivars GT28 (SAI1). In Saccharum hybrid CoJ64 cultivars have a similarity of $96.24 \%$ with PS 80.1694 sugarcane cultivar. In contrast to Saccharum hybrid FN-41 clone INV16 cultivars, Saccharum hybrid Pindar cultivar, and Saccharum robustum which has a kinship relationship based on Sus2 gene at $95.56 \%$ with PS sugar cane 80.1694. Saccharum hybrid cultivar FN-28 has a kinship relationship of $94.85 \%$ with sugar cane PS 80.1694. Saccharum spontaneum SES34 cultivar, and Saccharum hybrid cultivar H65-7052 had a kinship relationship of $94.81 \%$ with sugar cane PS 80.1694. Sorghum bicolor SAI$1 \mathrm{~b}$, and SAI-1c have a kinship relationship with sugar cane PS 80.1694 of $92.99 \%$.

Table 2. Forward and reverse sequences of ten primers designed (Vinayak et al. 2010)

\begin{tabular}{lll}
\hline Primer name & Forward sequence & Reverse sequence \\
\hline A & 5' TCG GGA CGA ATC TGT TGA G 3' & 5' GCA TAC AAA GGA CAA TAA TAA AAG A 3' \\
B & 5' GAT TCG ATG TGA TGG CAA GCA C 3' & 5' GCA TAC AAA GGA CAA TAA TAA AAG A 3' \\
MSSCIR43 & 5' ATT CAA CGA TTT TCA CGA G 3' & 5' AAC CTA GCA ATT TAC AAG AG 3' \\
MSSCIRI & 5' CTT GTG GAT TGG ATT GGA T 3' & 5' AGG AAA TGG ATT GCT CAG G 3' \\
SMC226CG & 5' GAG GCT CAG AAG CTG GCA T 3' & 5' ACC CTC TAT TTC CGA GTT GGT 3' \\
SMC1039CG & 5' AGG TGA GAG TTC CTG GCT TTC CA 3' & 5' TGT GCT GGC AAG CCC CTA CTT 3' \\
SCB07 & 5' ACG AGA ACC ACA GCC ACC AG 3' & 5' GGA GGT AGT CGG TGA AGT GC 3' \\
AI & 5' CAA GTT CTA CGC GTC CAA GAC 3' & 5' CAG ATG TCC GTG ACC ATT AGT 3' \\
SS & 5' TTG GGT ATG CTC GCT CTT CT 3' & 5' TAC TGA CTC CGC ACA AGC AC 3' \\
SPS & 5' TGA GAA GAG CTC GCT GAA CA 3' & 5' GCT AGC AGA GGG ACA ACC TG 3' \\
\hline
\end{tabular}

Table 3. BLAST NCBI Analysis of sugarcane sample PSJT 941 using AI primer

\begin{tabular}{lcccccc}
\hline Sequences producing significant alignments & $\begin{array}{c}\text { Max } \\
\text { score }\end{array}$ & $\begin{array}{c}\text { Total } \\
\text { score }\end{array}$ & $\begin{array}{c}\text { Query } \\
\text { cover }\end{array}$ & E value & Perc. ident & $\begin{array}{l}\text { Accession } \\
\text { genbank }\end{array}$ \\
\hline Saccharum hybrid cultivar GT28 (SAI5) & 346 & 346 & $50 \%$ & $9 \mathrm{E}-91$ & $80.85 \%$ & JX975050 \\
Saccharum hybrid cultivar FN-28 & 340 & 340 & $50 \%$ & $4 \mathrm{E}-89$ & $80.62 \%$ & $\mathrm{JQ} 982494$ \\
Saccharum robustum & 342 & 342 & $50 \%$ & $1 \mathrm{E}-89$ & $80.62 \%$ & AF062734 \\
Saccharum hybrid cultivar FN-41 & 335 & 335 & $50 \%$ & $2 \mathrm{E}-87$ & $80.40 \%$ & KC145806 \\
Saccharum hybrid cultivar GT28 (SAI9) & 335 & 335 & $50 \%$ & $2 \mathrm{E}-87$ & $80.40 \%$ & JX975055 \\
Saccharum hybrid cultivar Pindar (ShinvA) & 329 & 329 & $50 \%$ & $9 \mathrm{E}-86$ & $80.31 \%$ & AY302083 \\
Saccharum officinarum & 335 & 335 & $50 \%$ & $2 \mathrm{E}-87$ & $80.18 \%$ & AF062735 \\
Saccharum hybrid cultivar GT28 (SAI6) & 324 & 324 & $50 \%$ & $4 \mathrm{E}-84$ & $79.96 \%$ & JX975052 \\
\hline
\end{tabular}

Table 4. BLAST NCBI Analysis of sugarcane sample PS 80.1694 using SMC226CG primer

\begin{tabular}{|c|c|c|c|c|c|c|}
\hline Sequences producing significant alignments & $\begin{array}{l}\text { Max } \\
\text { score }\end{array}$ & $\begin{array}{l}\text { Total } \\
\text { score }\end{array}$ & $\begin{array}{l}\text { Query } \\
\text { cover }\end{array}$ & E value & Perc. ident & $\begin{array}{l}\text { Accession } \\
\text { genbank }\end{array}$ \\
\hline Saccharum officinarum cultivar 28NG210 & 220 & 220 & $25 \%$ & $3 \mathrm{E}-53$ & $96.30 \%$ & KC570327 \\
\hline Saccharum hybrid cultivar GT28 (SAI1) & 220 & 220 & $25 \%$ & $3 \mathrm{E}-53$ & $96.30 \%$ & JQ406875 \\
\hline Saccharum hybrid cultivar CoJ64 & 217 & 217 & $25 \%$ & $4 \mathrm{E}-52$ & $96.24 \%$ & KC570326 \\
\hline Saccharum hybrid cultivar FN-41 clone INV16 & 215 & 215 & $25 \%$ & $2 \mathrm{E}-51$ & $95.56 \%$ & KC145806 \\
\hline Saccharum hybrid cultivar Pindar & 215 & 215 & $25 \%$ & $2 \mathrm{E}-51$ & $95.56 \%$ & AY302083 \\
\hline Saccharum robustum & 217 & 217 & $25 \%$ & $4 \mathrm{E}-52$ & $95.56 \%$ & AF062734 \\
\hline Saccharum hybrid cultivar FN-28 & 359 & 359 & $43 \%$ & 7E-95 & $94.85 \%$ & JQ982494 \\
\hline Saccharum spontaneum cultivar SES34 & 209 & 209 & $25 \%$ & $7 \mathrm{E}-50$ & $94.81 \%$ & KC570328 \\
\hline Saccharum hybrid cultivar H65-7052 & 209 & 209 & $25 \%$ & $7 \mathrm{E}-50$ & $94.81 \%$ & AF083856 \\
\hline Sorghum bicolor SAI-1b allele & 224 & 314 & $58 \%$ & $3 \mathrm{E}-54$ & $92.99 \%$ & JX535516 \\
\hline Sorghum bicolor SAI-1c allele & 224 & 292 & $39 \%$ & $3 \mathrm{E}-54$ & $92.99 \%$ & FJ768686 \\
\hline
\end{tabular}


Table 4. BLAST NCBI Analysis of sugarcane sample Kidang Kencana using SMC226CG primer

\begin{tabular}{lcccccc}
\hline Sequences producing significant alignments & $\begin{array}{c}\text { Max } \\
\text { score }\end{array}$ & $\begin{array}{c}\text { Total } \\
\text { score }\end{array}$ & $\begin{array}{c}\text { Query } \\
\text { cover }\end{array}$ & E value & Perc. ident & Accession \\
\hline Sorghum bicolor & 324 & 324 & $95 \%$ & $1 \mathrm{e}-84$ & $85.58 \%$ & XM21461690 \\
\hline
\end{tabular}

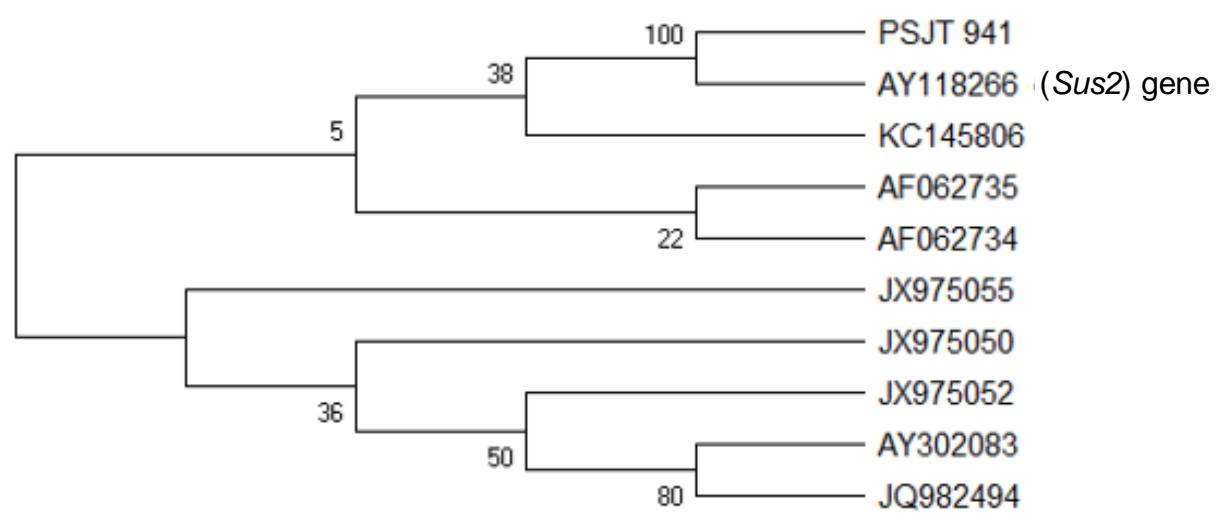

Figure 5. Phylogenetic tree of PSJT 941 based on Sus2 genes

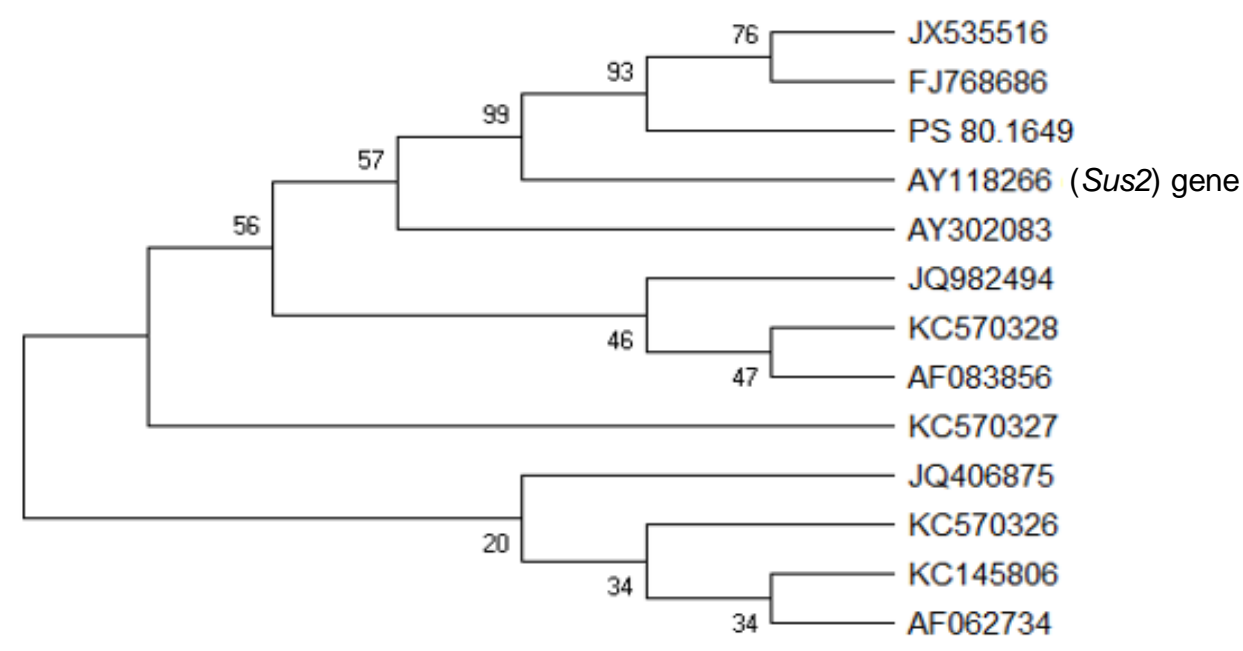

Figure 6. Phylogenetic tree of PS 80.1649 based on Sus2 genes

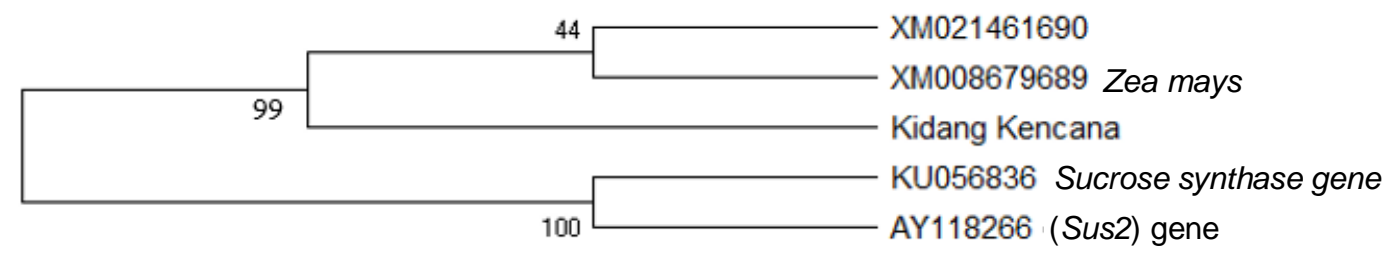

Figure 7. Phylogenetic tree of Kidang Kencana based on Sus2 genes 
Results of the BLAST analysis on NCBI using SMC226CG primer (Table 5) showed that the sugarcane sample of cultivar Kidang Kencana had a kinship based on Sus2 of $85.58 \%$ with Sorghum bicolor. Based on the results of the analysis obtained by conducting BLAST at NCBI using SMC226CG primer, it was found that the sugarcane samples from Kidang Kencana cultivars had a kinship based on Gen Sus 2 of $85.58 \%$ with Sorghum bicolor.

BLAST NCBI analysis on sugarcane PSJT 941 samples can be reconstructed into phylogenetic trees (Figure 5). Reconstruction of a phylogenetic tree using the NeighborJoining (NJ) method with Kimura-2-Parameter model of 1000 bootstrap replicates. From the phylogenetic trees formed, showed that sugarcane cultivar PSJT 941 had similarity sequence genes that were identical to the Sus2 gene (AY118266) which is $100 \%$.

BLAST NCBI analysis on sugarcane PS 80.1649 samples can be reconstructed into phylogenetic trees (Figure 6). Reconstruction of a phylogenetic tree using the Neighbor-Joining (NJ) method with Kimura-2-Parameter model of 1000 bootstrap replicates. From the phylogenetic trees formed, showed that sugarcane cultivar PS 80.1649 has similarity sequence genes to the Sus2 gene (AY118266) which is $99 \%$.

BLAST NCBI analysis on sugarcane Kidang Kencana samples can be reconstructed into phylogenetic trees (Figure 7). Sucrose synthase in the database at NCBI, one of which is the Sucrose synthase gene (KU056836) which was included in the reconstruction of the phylogenetic tree cultivar Kidang Kencana. This is done so that it can be used as a comparison between research data that has been obtained with the Gene Bank database at NCBI. Based on the resulting phylogenetic tree, it was seen that Sus2 was identical to the Sucrose synthase gene (KU056836) with similarity values displayed $100 \%$.

\section{Discussion}

According to Scortecci et al. (2012), total size of basic genome in sugarcane is about $760 \mathrm{Mbp}$ to $926 \mathrm{Mbp}$. The genome DNA isolation was success, indicated by the size of the band DNA is more than $10 \mathrm{Mbp}$ under the wall (Figure 1). Each amplification product with a specific target fragment will produce an amplification band of a specific size. According to Vinayak et al. (2010), the size of the fragments of amplified AI primer pairs is 50, 180, 210, 350, 390, and 500 bp. However, it is only the 500-bp DNA band that can indicate that the sugarcane plant has relatively high sucrose contents. The sizes of the fragments of amplified SMC226CG primer were 90, 180, 320, 430, 550 and 920 bp. However, it is only the 920-bp DNA band that can indicate that the sugarcane plant has relatively low sucrose contents. The results of amplification of AI primer pairs showed (Figure 2) the formation of fragments of varying sizes, namely $351,495,502,720,754,882$, and $1205 \mathrm{bp}$, in twenty-four sugarcane samples. This result is consistent with that of Vinayak et al. (2010). Their study demonstrated that, when the PCR products with AI primer contained DNA bands of $500 \mathrm{bp}$, the sugarcane had high sucrose contents. When the PCR products with SMC226CG primer showed DNA bands of $920 \mathrm{bp}$, the sugarcane had low sucrose contents. Also, the expression of Sus 2 in sugarcane is found to be strongly influenced by the presence of environmental stresses (Vinayak et al. 2010).

The difference in the size of base pairs is possible because the target DNAs had introns and exons of different lengths (Figure 3). Vinayak et al. (2010) demonstrated that the fragments of amplified AI primers have varying sizes. Despite the difference, both encode the same gene. This is evidenced by the resulting nucleotide sequences. The primary sucrose metabolism is regulated by several enzymes. Sucrose is enzymatically hydrolyzed in the vacuoles before mobilization. The extent and timing of sucrose accumulation in all individual segments correlate with a decrease in the regulation of the soluble acid invertase (SAI) activity above where high sucrose concentrations do not accumulate (Zhu et al. 1997). Modern sugarcane cultivars are very productive in the tropics. However, environmental stresses can affect the productivity of sugarcane, such as salinity stress not only affects the growth rate, but also affects the accumulation of sucrose in sugarcane stems (Rozeff 1995). Salinity tolerance is a complex process and is controlled by many genes. Those genes are expressed only when the plant is exposed to salinity. The choice of plant genotypes for tolerance to salinity is an important area of research. Numerous researchers have explored various plant responses to salinity. Sugarcane is one of the plants which is quite sensitive to salinity. However, differences in genotype will affect sugarcane species concerning salinity stress (Begcy et al. 2012).

The climate affects sugarcane growth and sugar production to a great extent. During the growing period, sugarcane plants require a lot of water, while when mature phase needs a dry condition for the growth to halt. When the rainfall remains high, the growth will continue and there will be no chance to mature, making the yield low. The temperature has a sufficiently high effect on sugarcane plant's growth and sucrose formation. The ideal temperature for sugarcane plants ranges from $24^{\circ} \mathrm{C}$ to $34^{\circ} \mathrm{C}$ with a temperature difference between day and night of less than $10^{\circ} \mathrm{C}$. Sucrose formation occurs during the day and will run more optimal at $30^{\circ} \mathrm{C}$. The formed sucrose will be stored on the stem starting at the bottom at night. The sucrose storage process is most effectively and optimally at $15^{\circ} \mathrm{C}$ (Begcy et al. 2012). Lingle and Irvine (1994) showed a correlation between the high sucrose synthase activity and an increase in the rate of sucrose accumulation and plant maturation. On the contrary, Zhu et al. (1997) showed no correlation between sucrose synthase activity and sucrose accumulation. These contrasting results may be caused by the effect of differences in genotypes among different varieties. Under several environmental stress factors above, sugarcane plants have resistance to the stress conditions, making them capable of growing optimally but reducing sucrose productivity by decreasing sucrose accumulation in the stem by activating sucrose synthase 2 . This condition is caused by the sucrose produced will be used to support the metabolic process, the growth and development under stress conditions, leading sucrose 
contents accumulated in the stem to decrease (Vinayak et al. 2010). Based on this description, the 24 sugarcane cultivars studied were identified as having sucrose synthase 2 in the genome, leading the 24 cultivars to experience decreased sucrose productivity under stress conditions of salinity, oxidative stress, or climate except for Bulu Lawang and Kentung cultivars.

Sneath and Sokal (1973) argue that a phenetic taxonomy is a classification system of an organism based on its similarity relationship. The similarity relationship is obtained from the level of character similarity among individuals without any specialization of certain characters. In the present study, the character used was the amplified fragments from the PCR method. The similarity dendrogram shows three clusters. Cluster A consists of 'PS 865', 'PS 951', 'PS 921', and 'PS 58'; Cluster B consists of 'Kentung'; and Cluster C consists of 'PSDK 923', 'PSBM 901', 'TLH 2', 'BL', 'PSJT 941', 'KK', 'PS 80.1649', 'PSCO 902', 'PS 80.910', 'PS 882', 'PS 862', 'PS 851', 'PS 881', 'PS 865', 'PS 384', 'VMC 76-16', 'BZ 132', 'PS 891', 'PS 41' (Figure 4). In general, the clustering illustrates the difference in the sequences of amplified DNA. The three clusters are formed by the kinship of sucrose contents related to acid invertase enzyme and also sucrose-synthesizing enzymes in sugarcane. Cluster B consists of Kentung cultivar that has a thick waxy layer a specific morphological structure, so it can control the rate of transpiration and regulate the water content in the stem. It causes sucrose content in Kentung cultivars different from the other cultivars.

All primer pairs used in the present study amplified genes that play a role in the mechanism identification of sucrose contents in sugarcane (Figure 2 and Figure 3). The presence of extreme environmental stresses can cause genetic mutations and ultimately affect the arrangement and sequence of nucleotides. The present study showed that amplified DNA bands were heterozygous as characterized by the appearance of amplified DNA bands with AI primer of $351,495,502,720,754,882,1205 \mathrm{bp}$, and the appearance of amplified DNA bands with SMC226CG primer of $90,180,320,430,550$ and 920 bp. With heterozygous bands, it can be assumed that the individual has a dominant allele and a recessive allele in its cell nucleus. Polymorphic bands are those appearing at a certain size, but not found in other samples. A polymorphic band is caused by the absence of amplification at a locus, caused by a difference in the sequence of nucleotide bases at the primer attachment point. The presence of polymorphic DNA band patterns is caused by differences in the base arrangement in each DNA sample. Thus, not all DNA samples can produce bands at a particular locus. DNA samples capable of producing bands indicate that the DNA has a complementary sequence with the primer. This difference can indicate genetic diversity both within and among populations (Sulistyawati and Widyatmoko 2017).

Results of Multiple Sequence Alignment of Sus2 using the molecular marker AI and SMC226CG primers showed a difference in nucleotide base sequences in $S u s 2$ from analog gene sequences in Gene Bank. Each gene has a different band length. The sugarcane samples used for sequences, PSJT 941, PS 80.1649, and Kidang Kencana, have the shortest sequence size since the primers used are only capable of doing amplification at a certain length, making the overall size of the gene not amplified. Differences in species, habitat, and environmental factors are among the factors that may cause differences in nucleotide sequences in analogous genes. Despite the similar function, there are differences in the nucleotide sequences. Likewise, despite the different genes with different functions in other species, genes having similarities in nucleotide sequences can be regarded as homologous genes.

Results of BLAST on NCBI with AI primer (Table 3) showed the gene sequences of sugarcane PSJT 941 had a fairly high similarity of $80.85 \%$ to Sus 2 Saccharum hybrid cultivar GF28 (SAI5) thus, it can be assumed that the above plants have a kinship based on the closeness with Sus2. Sus2 is sugarcane sucrose metabolizing enzymeencoding gene, one of which is acid invertase enzyme which could be detected in the present study using the molecular marker primer AI. Reconstruction of the phylogenetic tree on sugarcane PSJT 941 samples (Figure 5) using the Neighbor-Joining (NJ) method with Kimura-2Parameter model of 1000 bootstrap replicates. The phylogenetic tree showed that sugarcane cultivar PSJT 941 had similarity sequence genes that were identical to the Sus2 gene (AY118266) which is $100 \%$. These results prove that the DNA isolated was a Sus2 DNA fragment. In sugarcane cultivars PSJT 941 and Sus2 genes formed clusters with the gene sequence of Saccharum hybrid plants cultivar FN-41 (KC145806) and showed a considerable kinship with a similarity value of $38 \%$. Although it has quite a long relationship, the gene in Saccharum hybrid cultivar FN-41 is also capable of influencing invertase acid biosynthesis. Invertase acid is an enzyme that is used to hydrolyze glycosidic bonds between glucose and fructose in sucrose to produce invert sugar (fructose and free glucose). In sugarcane, invertase activity is the main key to regulating sucrose accumulation. In comparison plants, Saccharum officinarum (AF062735) and Saccharum robustum (AF062734) grouped into one cluster with 22\% similarity value. In comparison plants, Saccharum hybrid Pindar (ShinvA) cultivar (AY302083) with Saccharum hybrid cultivar FN-28 (JQ982494) grouped into one cluster with $80 \%$ similarity value which indicates that Sus2 gene kinship is quite close. In Saccharum hybrid cultivars GT28 (SAI6) (JX975052), Saccharum hybrid cultivars GT28 (SAI5) (JX975050), and Saccharum hybrid cultivars GT28 (SAI9) (JX975055) separated into different clades with different similarity values of $50 \%$ and $36 \%$. Kinship in comparable plants has similarity which is quite far adrift. This result shows that there is genetic variation based on Sus2 gene from sugarcane cultivar PSJT 941 with comparable plants in the database at NCBI.

Based on the analysis obtained by conducting BLAST at NCBI using the SMC226CG primer (Table 4 indicates that the kinship between Sus2 of sugarcane cultivar PS 80.1694 and Sus2 of other plants is very close, despite the slightly different nucleotides. Sucrose synthase 2 is one of the sucrose-metabolizing enzyme-encoding genes in 
sugarcane, which in the present study can be detected using the molecular marker SMC226CG primer. When a DNA band of 920 bp appears, the sugarcane has low sucrose (Vinayak et al. 2010). In Saccharum spontaneum cultivar SES34 (KC570328) with Saccharum hybrid cultivars H657052 (AF083856) grouped into one cluster and a similarity value of $47 \%$. Saccharum spontaneum SES34 cultivar and Saccharum hybrid cultivar H65-7052 have invertase acid proteins that play a role in the hydrolysis of glycosidic bonds between glucose and fructose in sucrose result in invert sugar (fructose and free glucose). In sugarcane, invertase activity is the main key to regulating sucrose accumulation. In Saccharum hybrid cultivars FN-41 clones INVI6 (KC145806) and Saccharum robustum (AF062734) grouped into one cluster with a similarity value of $34 \%$. Saccharum hybrid FN-41 cultivar INVI6 clone and Saccharum robustum have vacuole invertase enzyme, which belongs to family 32 of glycoside hydrolase (GH32) and is a key enzyme in sugar metabolism. This vacuole invertase enzyme hydrolyzes sucrose to glucose and fructose. In other comparisons, plants have similarity which is quite far a drift. It shows that there is genetic variation based on Sus2 gene from sugarcane cultivar PS 80.1649 with comparable plants in the database at NCBI. BLAST NCBI analysis on sugarcane PS 80.1649 samples can be reconstructed into phylogenetic trees (Figure 6). Reconstruction of the phylogenetic tree using the Neighbor-Joining (NJ) method with Kimura-2-Parameter model of 1000 bootstrap replicates. The phylogenetic tree showed that sugarcane cultivar PS 80.1649 has similarity sequence genes to the Sus2 gene (AY118266) which is 99\%. Saccharum spontaneum SES34 cultivar and Saccharum hybrid cultivar H65-7052 have invertase acid proteins that play a role in the hydrolysis of glycosidic bonds between glucose and fructose in sucrose resulting in invert sugar (fructose and free glucose). Saccharum hybrid FN-41 cultivar INVI6 clone and Saccharum robustum have vacuole invertase enzyme, which belongs to family 32 of glycoside hydrolase (GH32) and is a key enzyme in sugar metabolism.

The results of the BLAST analysis on NCBI using SMC226CG primer (Table 4) showed that the sugarcane cultivar Kidang Kencana had a kinship based on Sus 2 gene of $85.58 \%$ with Sorghum bicolor. It indicates that the kinship relationship of the Sus2 gene of sugarcane Kidang Kencana cultivar with $S u s 2$ gene in other plants is quite close although the nucleotides produced are slightly different. In the Gene Bank database at NCBI, Zea mays can be used as outgroup due to different genus but still in similar family with Saccharum officinarum. Therefore, Zea mays can be included in the analysis of the reconstruction of phylogenetic trees of sugarcane cultivars in Kidang Kencana (Figure 7). Sucrose synthase in the database at NCBI, one of which is the Sucrose synthase gene (KU056836) which was included in the reconstruction of the phylogenetic tree cultivar Kidang Kencana. This is done so that it can be used as a comparison between research data that has been obtained with the GenBank database at NCBI. Based on the resulting phylogenetic tree, it was seen that Sus 2 was identical to the Sucrose synthase gene (KU056836) with similarity values displayed $100 \%$. Despite the same family, the three plants have a low similarity of $85.58 \%$. This condition can be caused by differences in geographical location and environmental factors.

The present study showed that based on the PCR molecular markers, the formation of three large clusters: Cluster A consisting of 'PS 865', 'PS 951', 'PS 921', and 'PS 58'; Cluster B consisting of 'Kentung'; and Cluster C consisting of 'PSDK 923', 'PSBM 901', 'TLH 2', 'BL', 'PSJT 941', 'KK', 'PS 80.1649', 'PSCO 902', 'PS 80.910', 'PS 882', 'PS 862', 'PS 851', 'PS 881', 'PS 865', 'PS 384', 'VMC 76-16', 'BZ 132', 'PS 891', 'PS 41'. It is found that the addition of PCR molecular markers could produce polymorphisms in the twenty-four sugarcane cultivars as characterized by the appearance of heterozygous and homozygous bands. Sugarcane cultivars 'PS 865', 'PS 951', 'PS 921', and 'PS 58' clustered in one phenetic cluster since their amplified DNA had a similarity index of $57 \%$. The sugarcane 'Kentung' was separated from the other twenty-three cultivars since it only had a similarity index of $33 \%$ and 'PSDK 923', 'PSBM 901', 'TLH 2', 'BL', 'PSJT 941', 'KK', 'PS 80.1649', 'PSCO 902', 'PS 80.910', 'PS 882', 'PS 862', 'PS 851', 'PS 881', 'PS 865', 'PS 384', 'VMC 76-16', 'BZ 132', 'PS 891', 'PS 41' had a similarity index of $60 \%$. The high-sucrose encoding gene, Sus2, based on molecular markers used here has a sequence length of 7771 base pairs. The Sus 2 gene detected by the molecular marker AI primer will show high-sucrose sugarcane. On the contrary, Sus2 gene detected by the primer SMC226CG will show low-sucrose sugarcane. The present study showed that all sugarcane samples were detected as having low sucrose contents, except Bulu Lawang and Kentung cultivars.

\section{ACKNOWLEDGEMENTS}

The authors would like to express their gratitude for the completion and publication of the present study to the Faculty of Biology of Gadjah Mada University for the grant of Cooperative Research, Assessment and Development of Strategic Agriculture (KP4S) in the fiscal year 2018 number: 2052/UN1/DITLIT/DITLIT/LT/2018. Also, the authors would also like to thank to Indonesian Sweetener and Fiber Crops Research Institute (BALITTAS), Malang, East Java for their time and place provided to collect samples and for their good cooperation, to PT. Madu Baru for the permission granted to collect samples at the Polosio A Nursery, Poncosari, Srandakan, Bantul Regency, Yogyakarta, and their good cooperation.

\section{REFERENCES}

Begcy K, Mariano ED, Gentile A, Lembke CG, Zingaretti SM, Souza GM, Menossi M. 2012. A novel stress-induced sugarcane gene confers tolerance to drought, salt, oxidative stress in transgenic tobacco plants. PloS ONE 7 (9): e44697. DOI: 10.1371/journal.pone.0044697. 
Bull TA, Glasziou KT. 1979. Sugarcane. In: Lovett JV, Lazenby A (eds) Australian Field Crops. Angus and Robertson Publishers, Sydney.

Kementerian Pertanian Republik Indonesia. 2015. Statistik Pertanian. Pusat Data dan Sistem Informasi Pertanian Kementerian Pertanian Republik Indonesia, Jakarta. [Indonesian]

Kumar S, Stecher G, Tamura K. 2016. MEGA7: Molecular evolutionary genetics analysis version 7.0 for bigger datasets. Mol Biol Evol 33(7): 187.

Lingle SE, Dyer JM. 2004. Polymorphism in the promotor region in the sucrose synthase-2 gene of Saccharum genotypes. J Am Soc Sugar Cane Technol 24: 241-249.

Lingle SE, Irvine JE. 1994. Sucrose synthase and natural ripening in sugarcane. Crop Sci 34: 1279-1283.

Madden T. 2013. The BLAST Sequence Analysis Tool. The NCBI Handbook 2nd ed.

Rodiyah, Joedoro S, Triwibowo Y. 2004. Distribusi dan diversitas genetik bakteri diazotrof endofit pada tanaman tebu (Saccharum officinarum L.). Sains dan Sibernatika 17(2): 228. [Indonesian]

Rozeff N. 1995. Sugarcane and salinity - a review paper. Sugar Cane 5: 819.
Rutherford RA, Snyman SJ, Watt MP. 2014. In vitro studies on somaclonal variation and induced mutagenesis progress and prospects in sugarcane (Saccharum spp.). J Hortic Sci Biotechnol 89(1): 1-16.

Sambrook J, Russel DW. 1989. Molecular Cloning: A Laboratory Manual 2nd ed. Cold-Spring Harbor Laboratory Press, New York.

Scortecci KC, Creste S, Calsa Jr. T, Xavier MA. 2012. Challenges, opportunities and recent advances in sugarcane breeding. In: Abdurakhmonov I (ed.). Plant Breeding. InTech, Rijeka, Croat.

Sneath PHA, Sokal RR. 1965. Numerical Taxonomy: The Principles and Practice of Numerical Classification. W.H. Freeman and Company, San Francisco, CA.

Sulistyawati P, Widyatmoko AYPBC. 2017. Keragaman genetik populasi kayu merah (Pterocarpus indicus Willd) menggunakan penanda Random Amplified Polymorphism DNA. J Pemuliaan Tanaman Hutan 11 (1): 67-76. [Indonesian]

Vinayak V, Ashok K, Dhawan, Gupta VK. 2010. PCR Primers for identification of high sucrose Saccharum genotypes. Physiol Mol Biol Plants 16 (1): 107-111.

Zhu YJ, Komor E, Moore PH. 1997. Sucrose accumulation in the sugarcane stem is regulated by the difference between the activities of soluble acid invertase and sucrose phosphate synthase. Plant Physiol 115: 609-616 